\title{
ResearchOnline@JCU
}

This is the author-created version of the following work:

Kuttainen, Victoria (2020) Cross-colonial encounters and cultural contestation in Somerset Maugham's 'Rain'. In: Ehland, Christoph, and Gohrisch, Jana, (eds.) The Imperial Middlebrow: cross-colonial encounters and expressions of power in middlebrow literature and culture, 1890-1940. Brill, Amsterdam, NDL. pp. 140-158.

Access to this file is available from:

https://researchonline.jcu.edu.au/55838/

(C) Brill 2020. In accordance with the publisher's policies, the Author Accepted Manuscript of this publication is available Open Access from ResearchOnline@JCU.

Please refer to the original source for the final version of this work: 


\title{
Cross-colonial encounters and cultural contestation in Somerset Maugham's 'Rain'
}

\author{
Victoria Kuttainen, James Cook University
}

\begin{abstract}
'Can you wonder that when we first went there [to Samoa] our hearts sank? You'll hardly believe me when I tell you it was impossible to find a single good girl in any of the villages.' She used the word 'good' in a severely technical manner. 'Mr Davidson and I talked it over, and we made up our minds the first thing to do was to put down the dancing. The natives were crazy about dancing.'

'I was not averse to it myself when I was a young man,' said Dr Macphail.

'I guessed as much' [pronounced the missionary's wife], 'when I heard you ask Mrs Macphail to have a turn with you last night ...' (Maugham, 'Rain' 339)
\end{abstract}

Personal observations, cultural values, and character judgements structure and suffuse Somerset Maugham's most famous short story, 'Rain'. Set aboard ship, and then in a small guest house in quarantine, in the American naval outpost of Jazz-era Pago-Pago in Samoa, the story deploys the colonial, modernising Pacific as the setting for a clever tale that reflects upon colliding worldviews propelled by tumultuous changes of the first decades of the twentieth century. As various regimes of bio-political management are projected upon the island natives and displaced onto the body of the iconic Modern Girl Sadie Thompson, shelike the Pacific upon which the travels-becomes a site of spectacle, surveillance, control, and cultural contestation.

First appearing in April 1921 in the story 'Miss Thompson', published in The Smart Set magazine, Sadie quickly migrated from the page to stage and silver screen, where a string of re-castings and re-enactments earned her the status of one of the most recognisable types of the modern era. Re-titled 'Rain' when it appeared in Maugham's collection The Trembling of a Leaf: Stories of the South Sea Islands later that same year, the story of Sadie was reprinted dozens of times in both Britain and America. The stage version, dramatised by Colton and Randolph (1923), met acclaim in London's West End and ran for three years on Broadway where American theatre critics reviewed it as a 'supreme dramatic triumph' (Johnson 2009, 354). Film adaptations, based on the play, proliferated: from Gloria Swanson's starring role in the silent film Sadie Thompson (1928) and Joan Crawford's interpretation of Sadie in Rain (1932), to the 1946 race film Dirty Gertie and a 1953 3D musical starring Rita Hayworth, Miss Sadie Thompson (1953). Sadie was an ocean-crossing, platform-crossing, culture-crossing, and even race-crossing modern media sensation. Yet just as she attracted unprecedented attention, the character of Sadie Thompson has also been repeatedly dismissed and contained in ways that uncannily repeat tropes built into the dynamics of the tale.

Prevailing readings of Sadie Thompson reduce Maugham's compelling character to a onedimensional type and accuse the story of exoticism. This essay considers her more thoroughly and takes a panoramic look at the fictional woman who captured the attention of the world in the aftermath of the Great War and held it until well after World War II. It argues that one reason she has been taken up by modern print and performance cultures so thoroughly is that she appears to be purpose-built for interpretation, adaptations, and projections. Like the Pacific on which she travelled, endlessly evoked as a fantasy by scores of colonial travel writers, Sadie serves as a screen upon which observers cast their imagination.

Yet rather than serving up a mere rehashing of timeworn colonial fantasies of the Pacific, Maugham's story can be read, in part, as a knowing commentary upon them. Writing for and alongside the ascendance of Hollywood, Maugham was intensely aware of the way in which the increasing traffic in images drew upon fantasies of seductive starlets and beguiling tropical scenes. While distancing himself from the perceived exclusiveness of rarefied, intellectual, 
modernist literary circles, he was equally conscious of the way his own reputation, because of his association with cinema, was downgraded from serious writer to 'commercial hack pandering to the tastes of middlebrow audiences' (Calder 1978, 262). However, in its shrewd observations of cultural pretensions and appetites, 'Rain' may be understood as a paradigmatic example of what Faye Hammill calls the middlebrow's characteristic sleek 'polished surfaces' that 'conceal unexpected depths' (Hammill 2007, 6). As both a product of and commentary upon an increasingly image-based culture, the story of Sadie can be read as a wry reflection upon the contingencies of cultural value, the gender of modernity, and the cultural dynamics of cross-colonial encounters.

\section{Sadie's story}

Maugham's short story opens with deck-board reflections and conversations such as the one used in the epigraph to this essay, as the first-class passengers lean upon the rails in anticipation of their eventual arrival at Apia, the capital of British-controlled Samoa. Their ship steams toward the islands that figure as a source of interest and much discussion, but attention soon shifts to Sadie Thompson, a single woman from the lower decks. The shipboard exchange occurs between Dr Macphail, newly deployed to Apia to treat tropical diseases, and the missionary wife, Mrs Davidson, who has served many years in remote islands in northwest Samoa with her husband, the Reverend Mr Davidson. The travellers are impelled toward the islands on various campaigns of population management. As pillars of the church, the Davidsons represent an older, ecclesiastical campaign by which they take it upon themselves to forbid dancing and police dress codes (outlawing the customary lava-lava garment, replacing it with trousers and the Victorian Mother Hubbard dress). As an emissary of modern medical science with more liberal, relativistic viewpoints, Macphail defends dancing. He also represents the ambivalence to modernity so typical of Britons in the interwar era, as described by Paul Fussell in Abroad: British Literary Travelling Between the Wars. Eager to escape the terrible experiences that modern warfare has imposed on soldiers who witnessed the full scale of slaughter in the trenches, while also keen to put his medical expertise to use on the rarer cases of tropical diseases he has only read about so far, Macphail's travel is motivated by an anti-modern quest, yet undergirded by the modern mechanics of technological advancement responsible for the slaughter.

Cueing readers to differences in class and taste, as well as the judgement of others, all of which become thematic preoccupations of the story, the narrator notes that the relationship between these two couples 'was the intimacy of shipboard, which is due to propinquity rather than any community of taste' (Maugham 'Rain' 234-235). Further, 'their chief tie was the disapproval they shared of the men who spent their days and nights in the smoking-room, playing poker or bridge and drinking' (235). Mrs Davidson is shrill in her disapprobation of the lax morals and habits of the locals, particularly at the American outpost where the steamer touches down. When Dr Macphail opines that Mrs Davidson must feel she is nearing home as they approach the harbour, she is quick to differentiate the 'volcanic' port of American PagoPago ('Rain' 236) from the 'Davidson's district' ('Rain' 237) to the northwest. ${ }^{1}$

\footnotetext{
${ }^{1}$ The Samoan islands were strategically important to a number of imperial powers and became a site of international rivalry between them. Britain ceded Western Samoa (including the largest island with Samoa's only city - Apia) to the Germans from 1900 to 1914, when British control was restored via a New Zealand mandate. The less populated Eastern islands became American Samoa, which included the strategically important deep harbor of PagoPago, a whaling and naval station. In 'Rain', British-controlled Western Samoa is a Europeanised zone south of the British Gilbert Islands, identified by Maugham as home of the Davidsons (A Writer's Notebook 87); in contrast, American-controlled Eastern Samoa, and Pago-Pago in particular, is represented as a frontier contact zone ('Rain' 237).
} 
'Fixing the glasses on her nose', as 'she looked upon the green island with a ruthless stare' ('Rain' 237), she responds:

'I'm glad we're not stationed here [...] They say this is a terribly difficult place to work in. The steamers' touching makes the people unsettled; and then there's the naval station; that's bad for the natives. In our district, we don't have difficulties like that to contend with. There are one or two traders, of course, but we take care to make them behave, and if they don't we make the place so hot for them they're glad to go.' ('Rain' 237)

Mrs Davidson 'spoke of the depravity of the natives' with a 'vehemently unctuous horror' ('Rain' 237) especially regarding their 'shocking' marriage customs (238). Macphail, on the other hand, not only engages in dancing himself, but also notes with his characteristic pragmatism that the lava-lava seems 'suitable enough to the climate' ('Rain' 240). As they approach the harbour, Dr Macphail is fascinated: he looks upon the tropical scene with 'greedy eyes' ('Rain' 236). Further, as he surveys the bodies of indigenous Samoans who gather on the shore to meet the ship, men and women going about in sarongs with their limbs exposed, 'his professional eyes glistened when he saw for the first time in his experience cases of elephantiasis' ('Rain' 240). Despite their different attitudes, the Macphails and Davidsons share an interest in the management of bodies and populations, which impels their travel to Samoa. These interests suggest Foucauldian themes of bio-power often associated with the imperial project of surveillance and control, principally concerned with the regulation of race, class, sex, delinquency, and disease (Foucault 2008, 56; Stoler 112). As the natives soon fade into the background of the narrative, these preoccupations are transferred to the subject of Sadie Thompson, a 'second class passenger' ('Rain' 245), who had been among those enthusiastically engaged in the evening's shipboard dancing whom the missionary wife so thoroughly reviled.

The rising action begins promptly after the ship's arrival in the harbour. An epidemic of measles, 'a serious and often fatal disease amongst the Kanakas' ('Rain' 242) has broken out on the island and a case has developed in one of the crew of the schooner set to take them onward to Apia. Quarantined in Pago-Pago, the Macphails and the Davidsons find rooms in the upstairs quarters of a primitive boarding-house run by the 'half-caste' trader ('Rain' 243) Joe Horn and his native wife, across the bay from the Governor's residence. When Sadie, a single woman 'of twenty-seven perhaps, plump, and in a coarse fashion, pretty' enters the boarding house in the company of the quarter-master ('Rain' 245), Mrs Davidson recognises her from the party of dancers on the ship. She is a fast-talking, 'hooch' drinking American girl, 'loud-voiced and garrulous' (256), who earns Dr Macphail's admiration in bartering with the trader for a cut rate on her accommodation ('Rain' 246). The guests learn that she is en route to Apia to take a job as a cashier. She attracts immediate scorn from the wives: 'I wondered at the time what she was. She looked rather fast to me,' remarks Mrs Macphail as they recall her dancing with the quartermaster the night before ('Rain' 249), later pronouncing her 'extremely common' ('Rain' 255). 'Not good style at all,' agrees Mrs Davidson (249).

While the first-class passengers set up their rented rooms by taking precautionary measures to protect their bodies from disease-carrying mosquitos, sewing up holes in the nets above their beds, and discussing the need for the ladies to use pillow-slips to cover their lower extremities, Sadie welcomes the freedom of the tropics: her unpacking involves a hastily assembled gramophone, uncorked liquor, and an open door. Her short skirt exposes her legs that 'bulged over the tops of her long white boots' ('Rain' 245). Almost immediately, she begins to crank out jazz and to attract sailors, which develops into raucous parties in her lower rooms. Suddenly recalling that she boarded the ship at Honolulu, which harbours the notorious mixed-raced suburb of Ilewei - 'The plague spot of Honolulu! The Red-Light district [...] a blot on our civilization!' ('Rain' 258) - the missionary concludes that Sadie is a prostitute 'carrying on her trade, here!' (258). 
Davidson's island crusade to manage the bodies and souls of the native population is therefore instantly transferred to the project of exhorting Sadie to repent of her loose ways, and his campaign is focused upon the containment of her transgressive body. First, he threatens to ruin the trade of Joe Horn if the trader does not insist that Sadie closes her rooms to visitors. Then, he warns the governor that he will damage the governor's reputation in Washington if Sadie's prompt deportation is not arranged. Eventually, Reverend Davidson cuts off her hope of escape further westward across the Pacific toward future freedom and selfreinvention in Sydney, by determining that Sadie must return eastward to face 'the law' in San Francisco. There, she admits, there is a warrant for her arrest: "I beat it before they could get me...If the bulls grab me it's three years for mine" ('Rain' 281).

As the relentless rain suggests an atmosphere of oppression, the determined Reverend Davidson focuses his intensity on Sadie's religious conversion, a mission he equates with the relinquishing of her moral laxity regarding sex, drink, and jazz. The missionary's equally unrelenting proselytizing finally achieves its goal of wearing her down, though only after $\mathrm{Dr}$ Macphail has administered to her a 'hypodermic injection' ('Rain' 282). The story then delivers its final twist and denouement: the morning after Davidson's all-night prayer session, when newly repentant Sadie is due to board ship to San Francisco where she is apparently wanted for unspecified crimes, Davidson is found dead on the beach with a razor in his hand and his throat slit. Scarlet-lipped Sadie, once again 'the flaunting queen they had known at first' (246), resumes her lifestyle of jazz and drinking. When Dr Macphail forcefully enters her rooms to question her, her concluding lines suggest Davidson's sexual and moral hypocrisy, and hint at her appraisal of Macphail's complicity: 'You men! You filthy, dirty pigs! You're are all the same, all of you. Pigs! Pigs!' (295).

\section{Sadie's critics}

Certainly the character of Sadie and the story 'Rain' itself are not without obvious flaws, and the morally dubious attitudes that she and it embody have attracted a regular stream of critical dismissals. Justin Edwards names 'Rain' as one of many problematic and culturally insensitive neo-colonial narratives that draw on themes of 'eroticism and sexual emancipation in the context of travel' (Edwards 2001,13), in which the 'contact zone between cultures' is 'presented in erotic terms' (Edwards 2001, 14). He identifies the tale as an exemplar of the Western fantasy of Polynesian paradise structured on the logic of escape and authority that 'bind[s] eroticism to imperial control through an assertion of mastery over the primitive body which is linked to the female' (Edwards 2001, 18). Christopher Balme observes in it Maugham's 'condescending attitude to the native characters' (Balme 2007, 159) and its superficial portraiture of Samoans. 'Rain' is, Balme concludes, a narrative of displacement that shifts the missionary zeal's principal concern with colonial life onto the figure of the American woman, largely transferring 'native depravity onto Sadie' and reducing Samoans to 'little more than a shadowy presence' (Blame 2007, 158). Further, as Katie Johnson has commented, the narrative 'catered to Orientalist and colonialist desires, during a period of waning empire', and indulged readers in an 'exotic locale' which it created as 'a space where puritanical Anglos could unleash sublimated desires' (Johnson 2009, 354). Samoa is, in Maugham's story, a foil for Maugham's vision of 'the South Sea Islands as relentlessly malevolent and sexually forbidden' (Johnson 2009, 357). These criticisms are not without merit. Until recently, most readings of Sadie have been equally critical, accepting the stereotype of her that was rehashed in the countless plays and films adapted from the story, which stage her as a 'prostitute character,' or as Johnson has put it, 'a hooker-with-a-heart-of-gold' (Johnson 2009, 351).

As Jeffrey Meyers has observed, however, in fact Sadie 'does nothing immoral in Pago Pago' $(2012,2)$, and character judgements pronounced on her behaviour derive entirely from speculation. Critical readings such as these therefore repeat the dynamics of scrutiny, judgement, and surveillance that are at the heart of the tale. Further, the character described 
as most unsettled - 'trembling like a leaf' ('Rain' 293) - in Maugham's story is the hardedged, self-assured, and ultra-critical Mrs Davidson, after the suicide of her husband. Despite its exotic themes and dismissive treatment of indigenous subjects, the tale centres on the topic of the degradation of the white man in the tropics, the exposure of sanctimonious hypocrisy and complicity, and the fragility of the colonial project. The baselessness of 'the assumption of cultural and moral superiority by the British colonial elite' and their reliance on 'a condescending racism' that is 'easily upended' (McGuire 2012, 18) is a theme that John Thomas McGuire traces in several of Maugham's short stories and other works. In 'Rain,' as in his own non-fiction travel writing such as The Gentleman in the Parlour (1930), despite a prevailing ethnocentricism that is in evidence in most writing of the period, the European is more likely to be the kind of traveller Brian Musgrove observes as profoundly unsettled, 'wavering between two worlds,' and by no means the self-assured colonist, but rather a subject 'poised to split and unravel' (Musgrove 1999, 39). After all, Maugham's tour of Polynesia in 1916 and 1917, the first of many journeys that were to establish Maugham's reputation as a chronicler of the dying days of empire, culminated in the novel The Moon and Sixpence (1919), in which the principal character Charles Strickland, loosely based on the modernist painter Paul Gaugin, is perhaps the most loathsome Maugham creation of all time. Maugham was hardly a celebrator of or apologist for Europeans in the tropics.

\section{Reading and looking}

However, '[o]ne of the most interesting things about Maugham's story,' Amy Lawrence has noted, 'is that most of the action takes place 'off-stage' - the story is based around absences and enigmas' (Lawrence 1991, 41). The limits of knowledge about Sadie extend to what is actually going on in her boarding house room with the sailors whom she welcomes into it, what Sadie was really doing in Honolulu or would be working as in Samoa, why exactly she is reluctant to return to San Francisco (including the exact nature of the crimes she is wanted for), and the event which takes place between her and Reverend Davidson that precipitates his suicide. In contrast, the play, as Lawrence further observes, 'dramatizes almost every one of the scenes 'reported' to Macphail in the story' (Lawrence 1991, 44), a significant point given that it is Macphail's perspective through which the story is largely focalised. Discursive speculation about Sadie's character and about actions that take place 'off-stage' in the story is replaced, in the play, by 'on-stage' spectacle.

This dynamic extends to the way in which the Pacific is represented. While the luxuriant tropical scenery is a product of Macphail's 'greedy eyes' ('Rain' 236) in Maugham's original story - a subtle commentary upon Macphail's imperial gaze, in the play the Pacific and its islands becomes a source of visual pleasure for the entire audience, specified clearly in the script directions:

Hard by the rail of the verandah, bright green palm trees lift their branches, and brilliant flowers grow in riotous confusion. At the lifting of the curtain, the scene is bathed in the tense sunlight of early morning. Insects buzz and birds sing, every aspect is luxuriously, opulently drowsy. The sky and the water meet in a ring of magic silence.

In the distance we hear the low chanting murmur of native voices singing at their work. This is broken by the steamer's whistle. The stage is empty as the curtain rises until a native girl enters the scene from the verandah. She carries on her head a basket of pineapples. She wears the lava lava, the native costume of the South Seas a cotton swath hanging from her breasts to her knees in a knotted L. She walks indolently and gracefully. (Colton and Randolph 1923, 3)

The primitivism that is only suggested in the tale is replaced by an opening 'Polynesian Interlude' in Colton and Randolph's adaptation, including a 'Witch Doctor of Tangabura' (Colton and Randolph 1923, xiii), and detailed stage directions specifying the sordidness of Sadie's rooms that help establish her character: 'bedraggled,' 'in general bleakness,' and 
'covered with greasy matting' (Colton and Randolph 1923, 2). Additionally, the measles of the story, which many readers may have associated with the flu pandemic of 1918 from which no country was spared (and which exacted a particularly heavy toll upon Samoa), is changed in the play to cholera, a disease more directly associated with the tropics. This change makes the link between sordidness and the South Pacific more direct in the stage play, and therefore much less indirectly suggested than it is in the original story.

In the play, the transgressiveness of Sadie and of the tropics become spectacles for visual display and consumption. In contrast, in the story, the activities of the Europeans looking, and their speculation about what they see, are focalised. In fact, the act of visually surveying both the natives and the travelling girl regularly receives comment. In the first paragraph alone, four separate acts of looking are described in a tight economy of seven sentences: 'in sight,' 'searched,' 'he saw,' and 'and you saw' ('Rain' 234). In the second paragraph, three acts of appraisal occur across four sentences: disapproval, flattery, and carping ('Rain' 235). Looking translates to judgement across the whole tale and is a thematic trope built into the narrative structure, in which projection and interpretation - and the related dynamics of what is seen as opposed to what is said, or what is presumed in contrast to what is certain - offer themselves up as topics for enjoyment or analysis.

But the very visuality of the dramatic and filmic adaptations mean that directorial decisions interpret bodies and scenes for the audience, resolving ambiguities and replacing absences with presence. 'Maugham's irony,' Calder notes, 'often subtle and devastating on the printed page, is frequently the quality that film-makers could not capture or deliberately chose to eliminate' (Calder 1978, 266). Shades of rainy grey on the printed page become black-andwhite or garish and bright on the stage or screen, and this dynamic intensified in the years and adaptations that followed the play. While Calder notes that Maugham's 'tolerance' for both men and women's 'follies and vices' had 'appealed to many readers in the Twenties' (Calder $1978,263)$, these ambiguities were 'stamped out' in subsequent dramatizations, paralleling the way the missionary Davidsons have put an end to native dancing and other behaviour they cannot abide.

As many critics have noticed on more than one occasion, producers of films based on the Sadie Thompson story, all of which were modelled on the stage-play rather than Maugham's story, found themselves making changes to characters, either in anticipation of or in response to censorship codes. 'One of the Hays Office dicta being that the clergy should not be represented in a pejorative way' (Calder 1978, 264), Reverend Davidson was transformed into a mere moral crusader. Further, the character of Sergeant O'Hara was introduced to rescue the single woman, Sadie, through his proposal of marriage and to offer a tidy resolution to the drama. This resolved what Andrée Lafontaine identifies as a new social problem in the 1930s that characters such as Sadie embodied: the 'woman adrift - the unattached, young, working woman' (Lafontaine 2014, 5). Yet perhaps most remarkably, whilst - as Calder notes - typically '[Maugham's] stories were made blander, safer, and more narrowly moralistic than he had ever conceived them' (Calder 1978, 263), when this story was adapted to film, the character of Sadie was made into a more exaggerated strumpet than in the original tale.

As the word is displaced by the image in the translation of Maugham's work from print to stage and then screen, spectacle replaces speculation. The language by which readers principally come to know Sadie, through the recognition of her own brand of snappy American slang or by the description of the looking and judging of others that comes to fill narrative absences is, as Lawrence observes of most speech in the story, 'displaced in favour of visual representation' (Lawrence 1991, 35). '[W] ith each change,' Lawrence continues, 'the way woman is represented' in the embodiment of Sadie Thompson also undergoes transformations that reflect dominant social attitudes about 'the cultural position of women from the period of one adaptation to the next' (Lawrence 1991, 39).

As Jonathan Schroeder notes, following the observations of Laura Mulvey in her seminal article 'Visual Pleasure and Narrative Cinema,' '[f]ilm has been called an instrument of the 
male gaze, producing representations of women, the good life, and sexual fantasy from the male point of view' (Schroeder 1999, 208). In the 'Rain' films, this means not only that the woman is given fewer opportunities to speak, but also that her inner life is penetrated and opened out for all to see. In the Gloria Swanson silent film Rain (1928) Sadie's repentance and conversion scene, which takes place 'off-stage' in the story, and which is not directly narrated for the reader, is made into a public spectacle through the intensity of a fast cross-cutting montage series that focuses on Sadie's facial expressions as mimetic of her psychological state.

In her analysis of the complex transnational entertainment circuits that criss-crossed the Pacific in the interwar years, Angela Woollacott observes that even as actual mobility increased across this last ocean basin to open up for travel in the first decades of the twentieth century, rather than increasing understanding, the appetite for exoticised and eroticised imaginings of areas and peoples associated with this region fed a market for highly racialised and gendered images associated with star personas (2011, xx-xxi). Red-lipped starlets such as Dolores Del Rio became pin-ups for films that promoted the region in terms of libidinal desire. The spectacle of the Pacific was, as Anne Rees has noted, made alluring to modern audiences because of its 'saturation in Hollywood imagery' which 'mediated the travel experience' and fuelled cross-cultural misunderstanding (Rees 2017, 49). By the interwar period, the Pacific had become the on-location set and fantasised backdrop of what Sean Brawley and Chris Dixon have called 'Hollywood's South Seas.'

Capitalising on the varying mythologies of the fabled region as a site of glamour, romance, and escape, or primitive darkness and disease - myths that propelled actual travel there for tourism, on-location filming, missionary colonialism, trade, or medical anthropology, Maugham stages their collision in his story as a struggle between different worldviews and ways of being. The interpretation and translation of the story from page to stage and screen results in an intensification of the clash of different, competing cultural regimes of value and systems of representation which are at the very heart of the tale.

\section{The clash of representational systems and regimes of value}

Maugham himself was exquisitely conscious of the vicissitudes of reputation and critical judgement. A favourite of the Broadway stage, he was also a writer for Hollywood whose name lent films cachet when the medium of cinema was still unstable and regularly drew upon the cultural capital of the literary world for credibility. During the period that witnessed the rise of the star authors, Maugham was one of the brightest. But this association with commercial theatre and film downgraded his literary repute in the eyes of serious literary critics.

As Selina Hastings has observed in her 2010 biography, Maugham was initially regarded with respect as a promising young member of the literary intelligentsia, 'an honourable condition' Maugham explains in his own words, 'which some years later, when I became a popular writer of light comedies, I lost' (Hastings 2009, 84). While Maugham began his early career with serious literary ambitions as an author, and as the editor of the highbrow literary journal The Venture (84), by the interwar period he focused his ambitions on a wide audience, only to discover that as he faced increasing commercial success and fame, his reputation amongst the literati waned. 'I was not satisfied with the appreciation of a small band of intellectuals' he wrote in his own autobiography The Summing Up, 'I wanted no such audience as this, but the great public' (Hastings 2009, 111). So great was his public success in London's West End, with his first smash hit Lady Frederick, that he was dubbed 'England's dramatist' by the press, and the play ran for more than a year, marking a turn away from the serious dramatists of Galsworthy and Shaw into something fresh, that was immediately snapped up on Broadway (Hastings 2009, 108). 
On his arrival in New York, Maugham was an instant celebrity, and directly became the target of vociferous attacks from the intellectual elite. The literary critic Edmund Wilson called Maugham 'a half-trashy novelist, who writes badly, but is patronised by half-serious readers, who do not care much about writing' (Calder 1978, 262). Even if on its immediate reception writing was received as a contribution to high culture, as Hammill has explained in her work on literary celebrity between the wars, commercial success was often regarded as a sign of artlessness, and served to condemn many writers whose work came to be associated with the middlebrow (Hammill 2007, 3). The career and reputation of Somerset Maugham might serve as one of the most paradigmatic examples of these dynamics that beset writers of the modern period.

The problem of the abject middlebrow - in Virginia Woolf's famous words 'betwixt and between' $(1942,156)$ mass entertainment and highbrow culture - is ultimately a problem of social and cultural positioning, thematised in Maugham's story 'Rain' by the issues of reputation, respectability, judgement, and appraisal on which the action turns and character development hinges. 'Rain' is also a story that reflects upon a rapidly changing modern scene: 'the harsh notes of the mechanical piano' ('Rain' 234), 'the pitiless clamour of the pneumatic drill' (236), 'telegraphic instructions' (242), and 'the sound of a gramophone, harsh and loud, wheezing out a syncopated tune' (254) threaten both Macphail's fantasy of idyllic escape and Davidson's controlled project of civilising and purging the islands of 'sin'. In Jill Julius Matthews's estimation, the emerging forces of modernisation, globalisation, commerce, and Americanisation - which imbued mass and middlebrow cultures - were perceived by cultural elites everywhere as threats to and incursions on cultural ideals.

In literary domains, these forces were regarded as an assault on 'the pursuit of truth and beauty, unsullied by the vulgar claims of commerce' (Matthews 2005, 19). Yet, as Matthews continues, 'modernity refused that segregation, promiscuously mingling culture and commerce, the beautiful and the vulgar' (Matthews 2005, 19). As Matthews further observes: 'Representing that fusion most visibly were young women' (Matthews 2005, 19). A closeted homosexual, Maugham may have been particularly attuned to the dynamics Rita Felski has called 'the gender of modernity'. As Felski shrewdly observes, 'images of femininity were to play a central role in prevailing anxieties, fears, or hopeful imaginings about the distinctive features of the "modern age" (Felski 1995, 19).

According to Janice Radway, similar dynamics operated around the cultural status of the middlebrow and informed its active exclusion from serious culture by literary elites. Drawing on the metaphor of the 'fertile, sexualised body' that Radway claims has 'been traditionally used to demonize the materials and processes of popular culture' (Radway 2000, 210) she notes that 'bawdy, extravagant entertainments' were understood in such terms as a 'distinct social threat to the reign of the recognized, legitimate authority of culture' (Radway 2000, 210). The middlebrow, Radway explains, with its tendency and ability to make incursions on high culture from below, was 'understood precisely this way' (Radway 2000, 211).

'Traditional symbols and embodiments of beauty,' Radway explains, 'young women now engaged in selling and buying' came to 'symbolise commercial pleasures' (Radway 2000, 19) of dubious value that endangered their social respectability and threatened to tarnish their worth. Sadie, the 'cashier' who is appraised as 'brazen, brazen' by the upper class women ('Rain' 263), is linked with both trade and promiscuity, and is treated by the Davidsons in ways very similar to their treatment of traders: 'We take care to make them behave, and if they don't we make the place so hot for them they're glad to go' ('Rain' 237). The half-caste trader Joe Horn, as with other traders discussed by the Davidsons, is associated with mixed-race sex, which is perhaps also the greatest threat represented by both llewei - where men and women 'of all nationalities' mixed ('Rain' 259) - and Sadie herself.

The cultural mixing that is represented in the threat of miscegenation is a symbolic correlative of the cultural promiscuity embodied in the figure of the Modern Girl, who, as Matthews notes, 'became the subject and the metaphor at the heart of international modernity' 
(Matthews 2005, 19). This dynamic was particularly potent in the icon of the independent travelling woman, as Sarah Galletly has argued (Galletly 2017, 72). In the type Galletly calls the 'spectacular traveling woman,' whose image splashed across magazines and film screens throughout the 1920s and 1930s (Galletly 2017, 70), the very indeterminacy of her nature facilitated her rapid incorporation into cultural images such as films and advertisements. In these domains, she became a screen against which numerous fantasies and anxieties were projected against backgrounds of primitive escape or cultural sophistication.

In shipboard stories, of which 'Rain' may be considered one, these fantasies and anxieties take on added intensity. Whereas social distinctions are policed in an intensified way through separate first-class and second-class accommodations aboard ship, the collision of cultures and movement across various domains that occurs through travel threatens the logic of these segregations. Social mobility and geographical mobility collide in these narratives in the figure of woman-at-sea, an often particularly transgressive and culturally indeterminate form of Lafontaine's 'woman adrift' (Lafontaine 2014, 5). What Matthews observes about the modern young women in general could equally be said of Sadie Thompson in particular: 'She was simultaneously the sign of all that was wrong with the direction that society was taking and the promise of a brave new world' (Matthews 2005, 19). Her theatre, the Pacific, is either a zone of primitivism and vulgarity - which must be civilised and made to behave - or a new frontier where self-reinvention is possible and the Modern Girl can be free of the shackles of the past.

A product of the increased visuality of modern culture, the 'modern appearing woman,' Liz Conor has argued, was both the subject and object of an internationalising modern culture increasingly obsessed by spectacle. Women were empowered as subjects by their ability to adapt and manipulate new images of themselves. They hailed these opportunities for selfinvention and determination as new freedoms. Yet in the increasing association between images of woman and ocularcentric culture, women were also disempowered, increasingly affected by paternalistic controls and censorship, judged as objects of scrutiny, or consumed and exchanged in an accelerating traffic of images.

Revealingly, the 1923 play by Colton and Randolph was often deliberately staged as a melodrama, and New York audiences booed or hissed at Davidson or Sadie as if they were characters in a pantomime (Balme 2007, 162), acting out internal cultural tensions 'between the 'liberated' Charleston generation and the still-strong Puritan heritage in the United States' (Balme 2007, 163). Yet the film adaptations, displaced in time and place from the era of flappers and the milieu of post-war freedom and frivolity that characterised the metropolitan scene of the 'Roaring Twenties', removed this element of audience participation, and deepened both the moralistic interpretation and immoral intensity of Sadie as prostitute rather than a subject of dramatic debate.

As an author of magazine fiction, whose stories were regularly adapted for stage and screen, and as a writer for film and commercial theatre, Maugham was deeply associated with the market. Yet his subtle, understated stylistics and his literary reputation fit the description Faye Hammill has offered of authors whose project was 'not wholly aligned with either high modernism or popular culture' (Hammill 2007, 6). Maugham can be connected with those authors in whose writing Hammill traces a thematic contestation of cultural values, as well as a 'preoccupation with style, taste, imitation, and social performance' which she tentatively associates with a 'middlebrow perspective' (Hammill 2007, 5). These suffuse Maugham's work as a writer highly attuned to the way that the figure of the Modern Girl was similarly demonised by highbrow culture or made the sweetheart of market modernity.

\section{The Space Between}

Maugham was also acutely aware that the dynamics that structured modern acclaim and approbation often played out in terms of the collision of the culture of letters with the rise of 
commercial image-based entertainment in ways that were often loosely translated as a culture war between the traditional, aristocratic English values and ascendant American popular culture. These dynamics were woven into the original story.

As Ashcroft et al explain, drawing from Abdul JanMohamed's work on allegory, by revealing the 'binarisms' that structure colonial discourse and imbue colonialist texts, such as self and other, master and subordinate, civilised and primitive, black and white, or female and male, narratives that lay bare this architecture structuring the imperial project 'can promote an active reading' characterised by 'subversion' (Ashcroft et al 1995, 6). In JanMohamed's formulation, the colonialist dynamic itself is one entirely based on projection and spectacle, in which the imperialist imposes a fantasised image upon the other which is actually the mirror image of himself: a figure JanMohamed connects to Lacan's 'imaginary.' In contrast, the 'symbolic' intervention of self-conscious language, he argues, can allow a text to manipulate, critique, or redeploy these codes.

In 'Rain' Maugham draws attention to a series of binaries that underpin the imperial project in the Pacific: for instance, 'natives' ('Rain' 238) versus 'white people' ('Rain' 239), and 'depravity' ('Rain' 237), 'wickedness' and 'sin' ('Rain' 252) versus 'moral' ('Rain' 240), 'Christianised' ('Rain' 241), 'civilisation' ('Rain' 258). Further, a series of centres and peripheries structure the plot. Among them, the Europeanised Apia is positioned in contrast to the American naval outpost of Pago-Pago, and the New England origin of the Davidsons ('Rain', 249) is positioned against the old England of the Macphails, who have left behind the 'soft English rain' ('Rain' 265). These binaries, largely structured around ideas about new and old worlds, also contain their own chronotopes. The missionaries represent an earlier form of colonialism, and the doctor and his wife its modern equivalent. As Felski explains, 'the modern was deeply implicated from its beginnings with a project of domination,' and in 'discourses of colonialism [...] the historical distinction between the modern present and the primitive past was mapped onto spatial relations between Western and non-Western societies' (Felski 1995, 14).

Yet, Maugham redeploys the Pacific, and particularly Samoa - halfway between 'Sydney' and 'Frisco' ('Rain' 274), as an ambiguous borderland, a space between competing regimes of value and culture. In his conception, as the new American 'frontier' expands westward across the Pacific and encounters older forms of Europeanised colonialism, the neat logic of these binaries is undone. If the missionary couple presented an early project of modernisation there, they now represent a relative 'past.' The Davidsons have been labouring in the Pacific for many years ('Rain' 249) while the rest of the world has been further modernising. Their attitudes about dancing, jazz, and sex appear somewhat outdated. Dr Macphail, in particular, finds Davidson's dogmatism 'vaguely troubling' ('Rain' 242), and urges him to consider that 'there may be difference of opinion about what is right' ('Rain' 271). Rather than condemning Sadie as Davidson does, Dr Macphail 'found Miss Thompson's effrontery amusing' ('Rain' 264) and 'admired the effrontery with which she bargained' ('Rain' 246). In Maugham's Pacific, where east and west meet, the old and the new also collide and co-mingle. The contest of competing values takes place in an interpretive struggle and representational challenge over the body of the American Modern Girl. This, embodied by Sadie, becomes in this environment particularly ambiguous and somewhat inscrutable: a figure of potential emancipation on the one hand, or a body requiring management and containment, on the other.

By drawing attention to the acts of judgement and appraisal undertaken by the Macphails and the Davidsons upon the islands of Samoa and the body of the woman, Maugham allows the story to become a subtly ironic commentary upon the grammar that structurally underpins the mythos of the region, where the logic of binarisms upon which the European relies to order his vision is stretched its furthest frontier, and the categories of primitive and modern, vulgar or advanced, and bad or good threaten to collapse. The presentation of Sadie as a fasttalking, hooch-drinking, jazz-listening, cosmetics-wearing working and travelling woman dressed in revealing clothes is apropos to the accelerated culture of spectacle in the highly 
visualised, consumer-driven, faster pace of early twentieth century modern life and the expansive, feminising marketplace as it reaches across the Pacific. Sadie may in fact be a prostitute, or she may only be a Modern Girl: the recognised, legitimate authority by which appraisal or judgment can take place collapses in this space.

Chris Dixon and Prue Ahrens argue that ' $[\mathrm{t}$ ] he Pacific, as Westerners understood it, was always more imagined than real, signifying a fantasy rather than an understanding of the region' (Dixon and Ahrens 2010,1). Across the story collection The Trembling of a Leaf in which 'Rain' was printed, Maugham often engages the Pacific as a setting for drawing attention to the mechanics of projection, interpretation, and evaluation. Increasingly the subject of feminised celluloid images in the first decades of the twentieth century, the Pacific emerges in this tale as a mirror-space for a culture increasingly obsessed with spectacle and fantasy.

In this way it is perhaps not just ironic but also appropriate that Sadie was subsequently made the subject of so many stage and film interpretations. In each instance, the medium of film intensified the embodied visibility of the character, invited the 'inscrutable Pacific' to be gazed upon, and forced ambiguities into resolutions. A succession of 'scarlet-lipped' actresses and South-Seas loving filmmakers thus 'showed' Sadie and the exotic Samoan setting to the audience, re-enacting the culture of consumption, entertainment, display, regulation, adjudication, and dismissal out of which this creature and her story first emerged. In this process, Sadie Thompson became a screen for the anxieties and fantasies of her time, set upon no more appropriate stage than that very in-between oceanic space of the modern Pacific, where old became new in Hollywood fantasies that offered a 'primitive' and 'exotic' world up for consumption.

Maugham's story of Sadie is set at the expanding frontier of the New World amidst an expanding culture of surface images, snap judgements, and quick interpretations, at the interface of their collision with older, more authoritarian and less relativistic but somewhat antiquated values. His narrative is focalised through the perspective of Dr Macphail, a 'timid man' ('Rain' 250), who serves as a go-between figure to mediate between different regimes of taste and judgement: the 'low' character of Sadie and the 'high' handedness of the 'exclusive' Reverend Davidson ('Rain' 235). But just as Sadie's interpreters fill the space of spectacle with their own speculations and projections, and as she then becomes a mirror of their worldview, a similar dynamic is replicated and intensified as she is translated from page to screen. Her figure is interpreted for consumption, and her complexity cast aside. Whereas Maugham's story may be read as a commentary upon those who judge or appraise her behaviour, whose roles are also to correct souls and manage native bodies, the visual economy of stage and cinema reduces her complex character to spectacle, and Maugham's subtle irony to sensation.

In writing from the space of the middlebrow, Maugham drew in large audiences for his work whilst also developing a sleek, polished magazine style that belied his literary complexity. The story of Sadie Thompson may be seen as a parable of taste, interpretation, culture, class, and judgement. Yet elements of the tale that allow it to serve as a clever critique of the very operations of judgement and spectacle from which its author himself had attracted both scorn and success are eclipsed by the story's own absorption within the dynamics of mass consumption and cinematic pleasure.

\section{Works Cited}

Bill Ashcroft, Gareth Griffiths, and Helen Tiffin, 'Issues and Debates: Introduction', The Post-Colonial Studies Reader (London: Routledge, 1995), 7-11.

Christopher Balme, Pacific Performances: Theatricality and Cross-Cultural Encounter in the South Seas (London: Palgrave Macmillan, 2007).

Sean Brawley and Chris Dixon, Hollywood's South Seas and the Pacific War (New York:

Palgrave Macmillan, 2012). 
Robert L Calder, 'Somerset Maugham and the Cinema' Literature/Film Quarterly 6:3 (1978) 262-273.

John Colton and Clemence Randolph, Rain: A Play in Three Acts (New York: Boni and Liveright, 1923).

Liz Conor, The Spectacular Modern Woman: Feminine Visibility in the 1920s (Bloomington, IN: Indiana University Press, 2004).

Chris Dixon and Prue Ahrens, 'Traversing the Pacific: Modernity on the move from coast to coast', in Chris Dixon and Prue Ahrens (eds) Coast to Coast: Case Histories of Modern Pacific Crossings (Newcastle Upon Tyne: Cambridge Scholars Publishing, 2010), 1-7.

Justin Edwards, 'Polynesian Paradises: Explorations in Hollywood Island Drama', American Studies in Scandinavia, 33: 1 (2001), 1-25.

Michel Foucault, The Birth of Biopolitics: Lectures at the College de France 1978-1979, Michel Senellart (ed.), Graham Burchell (trans.) (London: Palgrave Macmillan, 2008).

Rita Felski, The Gender of Modernity (Cambridge MA: Harvard University Press, 1995).

Sarah Galletly, 'The spectacular traveling woman: Australian and Canadian vision of women, modernity, and mobility between the wars', Transfers 7:1 (2017), 70-87.

Faye Hammill, Women, Celebrity, and Literary Culture (Austin, TX: University of Texas Press, 2007).

Selina Hastings, The Secret Lives of Somerset Maugham (London: John Murray, 2009).

Abdul R JanMohamed, 'The economy of Manichean allegory,' (1985). In The Post-Colonial Studies Reader, Bill Ashcroft, Gareth Griffiths, and Helen Tiffin (eds), (London: Routledge, 1995), 18-23.

Katie N Johnson, 'Before Katrina: Archiving performative downpours and fallen women named Sadie in "Rain" and "The Deluge"', Modern Drama 52:2 (2009), 351-368.

Andrée Lafontaine, Sink or Swim in Liquid Modernity: The Chronotope of the Modern Woman in Early 1930s Hollywood (PhD thesis, Concordia University), 2014.

Amy, Lawrence, Echo and Narcissus: Women's Voices in Classical Hollywood Cinema (Oakland, CA: University of California Press, 1991).

-- 'Rain: Theorising the transitional film', Quarterly Review of Film and Video 11:4 (1989), 2123.

Jill Julius Matthews, Dance Hall and Picture Palace: Sydney's Romance with Modernity.

(Sydney: Currency, 2005).

Somerset, Maugham, 'Miss Thompson', The Smart Set, 64:4 (April 1921), 3-26.

-- 'Rain', The Trembling of a Leaf (1921), (London: Heinemann, 1974), 234-298.

-- A Writer's Notebook, (London: Heinemann, 1949).

John Thomas McGuire, 'Rending the veils of illusion: W Somerset Maugham's "The Letter" and its two definitive film interpretations', Framework: The Journal of Cinema and Media, 53:1 (2012), 7-21.

Jeffrey Meyers, 'Tis a pity she's a whore: Conrad's Victory and Maugham's "Rain"', Notes on Contemporary Literature, 42:1 2012, 1-2.

Laura Mulvey, 'Visual pleasure and narrative cinema', in Leo Braudy and Marshall Cohen (eds) Film Theory and Criticism: Introductory Readings, (Oxford: Oxford University Press, 1999), 833844.

Brian Musgrove, Travel Writing and Empire: Postcolonial Theory in Transit (London: Zed Books, 1999). 
Janice Radway, A Feeling for Books: The Book-of-the-Month Club, Literary Taste, and MiddleClass Desire. (Chapel Hill: University of North Carolina Press, 2000).

Anne Rees, 'Stepping through the silver screen: Australian women in the United States, 1920s1950s', Journeys 17: 2 2017, 49-73.

Jonathan Schroeder, 'Consuming representation: A visual approach to consumer research', in Representing Consumers: Voices, Views and Visions (London: Routledge, 1999), 193-230.

Ann Laura Stoler, Race and the Education of Desire: Foucault's History of Sexuality and the Colonial Order of Things (Raleigh NC: Duke University Press, 1995).

Virginia Woolf, 'Middlebrow,' in The Death of the Moth and Other Essays. (London: Hogarth Press, 1942), 112-19.

Angela Woollacott, Race and the Modern Exotic (Melbourne Monash University Press, 2011). 